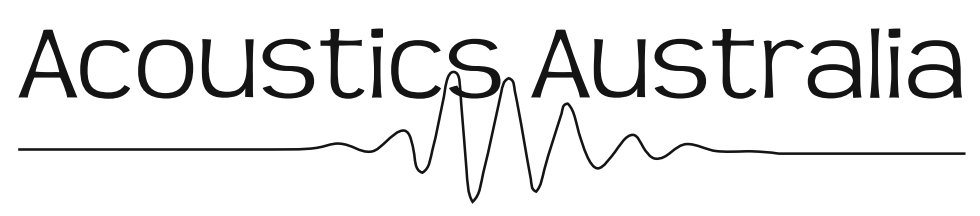

Acoustics Australia

Editorial Board

Editor-in-Chief:

Marion Burgess (Australia)

Assistant Editor-in-Chief:

Con Doolan (Australia)

Managing Editor:

Truda King (Australia)

Ross Chapman (Canada)

Densil Cabrera (Australia)

Nicole Kessissoglou (Australia)

Steffen Marburg (Germany)

Jer Ming Chen (Singapore)

George Dodd (New Zealand)

Frits van den Berg (Netherlands)

Acoustics Australia is published by the Australian Acoustical Society

(A.B.N. 28000712 658)

ISSN 0814-6039

Responsibility for the contents of articles and advertisements rests upon the contributors and not the Australian Acoustical Society.

All articles and technical notes (but not Acoustics Forum and Letters) are sent for peer review before acceptance. Acoustics Australia is abstracted and indexed in all major data bases and has an Impact Factor of 0.630 (2018).

Acoustics Australia

The papers and technical notes are available from the journal website www. springer.com/engineering/journal/40857. All members of the Australian Acoustical Society have free access to the papers and technical notes but must log in via the member area of the AAS website and follow the link to the journal.

\section{Editorial Enquiries}

The Editor, Acoustics Australia

AcousticsAustralia@acoustics.asn.au

www.acoustics.asn.au

Submissions

All Articles

www.springer.com/engineering/

journal/40857

News, New Products

and Books for Review

acousticsaustralia@acoustics.asn.au

Subscription Enquiries

www.springer.com/engineering/

journal/40857

Advertising

Mrs Leigh Wallbank

Tel (02) 95284362

wallbank.leigh@gmail.com
Vol. 47 , No. 2

August 2019

ACOUSTICS NEWS AND REGULAR ITEMS

Editorials

Abstracts

AAS News

News from the Divisions

Acoustics News

Obituary

Acoustics Forum

Simple Reverberation Time Specifications - A Trap For The Unwary

Peter Patrick

New Products

Book Review

Future Conferences

Sustaining Members Listing

Diary

\section{GENERAL SUBMISSIONS}

\section{Original Papers}

Automatic and Efficient Fault Detection in Rotating Machinery using Sound Signals

Muhammad Altaf, Muhammad Uzair, Muhammad Naeem, Ayaz Ahmad, Saeed Badshah,

Jawad Ali Shah, Almas Anjum

The Impacts of Pollution for New High-Speed Railways: the Case of Noise in Turkey

Yasin Sarikavak, Alistair Boxall

Analytical Modelling of Sound Transmission Through Finite Clamped Double-Wall

Panels with Magnetic-Linked Stiffness

Akintoye Olumide Oyelade

Effect of Element Failures on the Performance of Passive Towed Array Sonars

Jojish V. Joseph, Niranjana Radhakrishnan, Sooraj K. Ambat

Near-Field Variation of Loudness with Distance

Zhushu Chen, Dongxing Mao

Delving into the Two-Dimensional Structure of a Cold Eddy East of Taiwan and Its Impact on Acoustic Propagation

Cheng Chen, Ya Gao, Fenggang Yan, Tao Jin, Zhiquan Zhou 


\section{- Bradford}

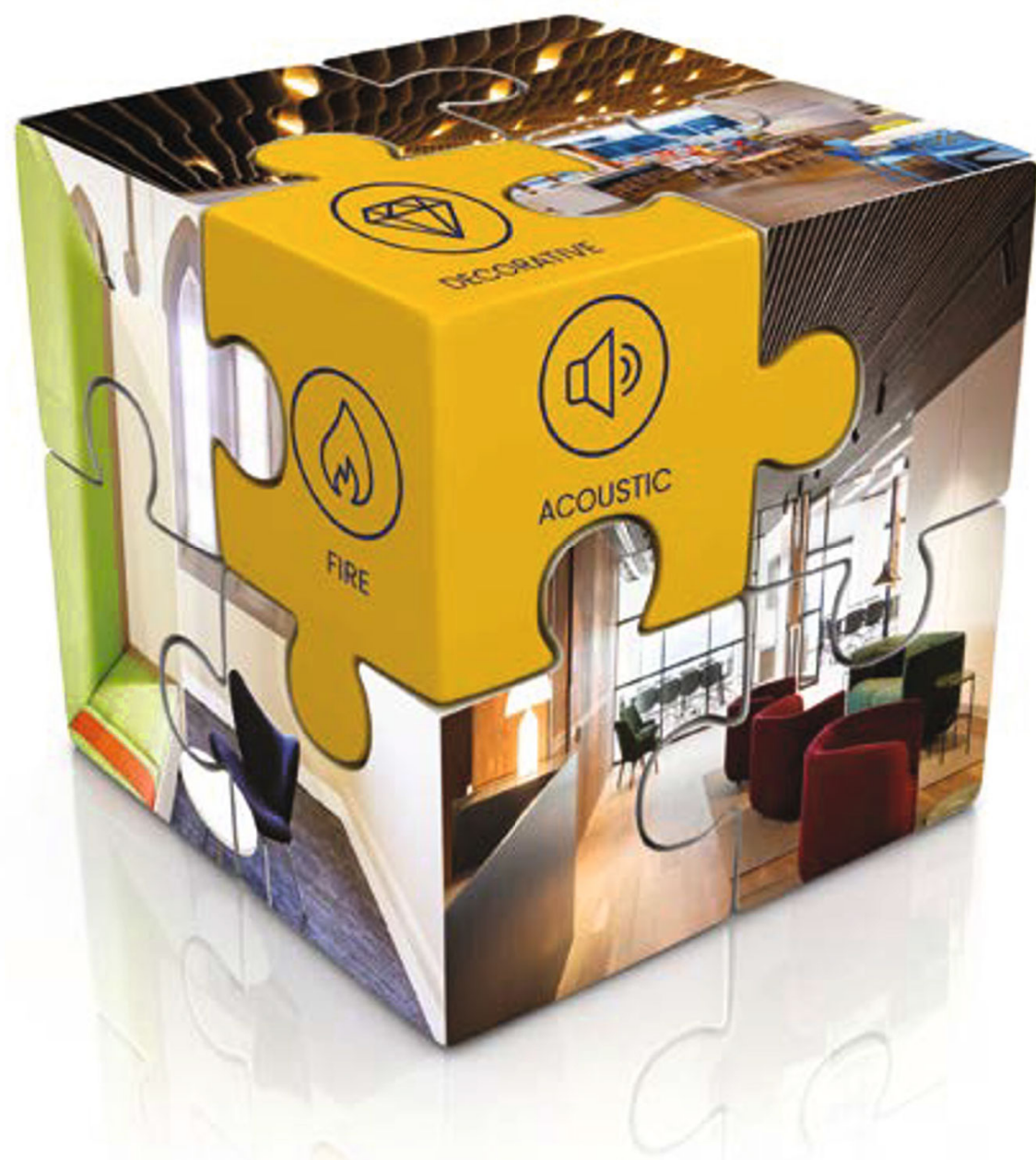

\section{Solutions to fit your project}

Not every project will fit the mould. Just one type of insulation may not suit all applications. As insulation experts, Bradford has a wide range of insulation solutions for fit-out with an extensive portfolio including non-combustible glasswool as well as Group 1 rated decorative polyester products to suit your unique project needs.

BradfordInsulation.com.au | 1300850305 


\section{FROM THE PRESIDENT}

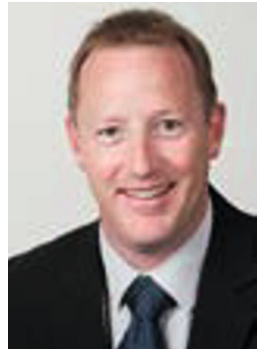

The use of drones and aerial vehicles for transportation of people and goods is a rapidly evolving technology. Uber has recently announced plans to introduce an aerial ridesharing service, Uber Air, with commercial operations to commence in 2023, and trials in Melbourne to commence as early as next year. Along with this, Google has also launched an air delivery business in Canberra using drones to deliver fast food.

So, it seems that in a very short time frame we could have an exponential increase in the number of drones taking to the skies in Australia for transportation purposes, which I believe is fantastic (could you imagine using a drone to drop off a noise logger?), but how do we deal with the potential new noise impacts? Currently, a quick Google search of "drone noise complaint" led me to the Australian Government Civil Aviation Safety Authority (CASA) website, which stated the following in relation to noise "As the safety regulator, the issue of aircraft (drone) noise is not within our responsibility. We recommend you contact the drone operator (if known) or make an aircraft noise complaint to Airservices Australia."
Currently in Australia, the noise impacts associated with the transportation of people and goods via road and rail is regulated at the State Government level, with air transportation being regulated at a Commonwealth Government level. Regulation of aircraft noise is dealt with via a noise certificate, which are issued for aircraft of 12 tonnes mass or greater, and at a planning level through the development of ANEF's to regulate the type of development surrounding an airport. As such, drone noise is currently unregulated.

In my opinion, I believe that the potential noise impacts from transportation drones should be dealt with at a State Government level, ether via amendments to existing transportation noise policies, or the development of new noise policies to deal with these new noise sources. However, the fact remains that this is not the case and as such it appears that by default it is the responsibility of Airservices Australia, who are seemingly tasked with dealing with this potential issue using current regulations and controls designed for large commercial aircraft operating at airports.

Therefore, I put the question back out to the acoustic community, what should we be doing to ensure we are ready for this potential new noise issue? And what can we do to offer our support (to bodies such as Airservices Australia) in navigating this new challenge?

Simon Moore, President, AAS

\section{FROM THE CHIEF EDITOR}



In this issue we have a diverse range of papers from researchers around the world. Unfortunately, from the high number of submissions to our journal it is only rarely that a journal article has been submitted from Australasia. As this is the time many are preparing manuscripts for the AAS conference in November I urge you to consider the option to expand/extend the content of the conference paper into a research article for the journal and submitted via Springer.

As an alternative to a research manuscript we have a section on Forum articles in this front section of each issue of the Journal.
Such articles are intended to initiate discussion and comment from other practitioners or to report on interesting findings/outcomes from projects; as is the case for the Forum article in this issue. More information on the requirements for Forum articles can be found from www.acoustics.asn.au/journal/Template_FORUM_inst to auth.pdf

In the lead up to each issue we follow up with the Divisions for their activities news and also try to keep a watch on any interesting items in the media. If you are aware of any acousticsrelated finding or activity in our region then please forward to us AcousticsAustralia@acoustics.asn.au for inclusion in the news section.

Marion Burgess, Editor in Chief

\section{AUSTRALIAN ACOUSTICAL SOCIETY ENQUIRIES}

\section{NATIONAL MATTERS \\ * Notification of change of address \\ * Payment of annual subscription \\ Julie Sobolewski - General Secretary Australian Acoustical Society \\ PO Box 1843 Toowong DC QLD 4066 \\ Tel: (07) 31222605 \\ GeneralSecretary@acoustics.asn.au www.acoustics.asn.au/joomla/}

\section{AAS MEMBERSHIP}

For 2019/20 Financial Year (Inc. GST):

Fellow and Member .............. $\$ 160$

Graduates ............... \$122 - \$160

Associate and Subscriber............\$122

Retired and Maternity .............. $\$ 48$

Students and retired fellows ........ No Charge

\section{DIVISIONAL MATTERS}

Enquiries regarding membership and sustaining membership should be directed to the appropriate State Division Secretary

AAS - NSW Division

Laura Keen

Tel: (02) 89340035

laura.jane.keen@gmail.com

AAS - QLD Division

Richard Devereux

Tel: (07) 32170055

rossd@acran.com.au
AAS - SA Division

Adam Cook

Tel: (08) 71006400

adam.cook@aecom.com

AAS - VIC Division

Dr Marc Buret

Tel: (03) 84582671

vic-secretary@acoustics.asn.au
AAS-WA Division

Benjamin Farrell

Tel: (08) 94745966

ben@gabriels.net.au 


\section{ACOUSTICS AUSTRALIA 47(2), 2019 ABSTRACTS}

The full papers for these abstracts can be found in the online version of Acoustics Australia.

Members of the Australian Acoustical Society should access via the member login of the AAS website. Access for all others is via $\mathbf{h t t p : / / l i n k . s p r i n g e r . c o m / j o u r n a l / 4 0 8 5 7 ~}$

GENERAL SUBMISSIONS

ORIGINAL PAPERS

\section{AUTOMATIC AND EFFICIENT FAULT DETECTION IN ROTATING MACHINERY USING SOUND SIGNALS}

Muhammad Altaf ${ }^{1}$, Muhammad Uzair ${ }^{2}$, Muhammad Naeem ${ }^{3}$, Ayaz Ahmad $^{1}$, Saeed Badshah ${ }^{3}$, Jawad Ali Shah ${ }^{4}$, Almas Anjum ${ }^{5}$

${ }^{1}$ COMSATS University Islamabad, Wah, Pakistan

2 University of South Australia, Adelaide, Australia

${ }^{3}$ Department of Mechanical Engineering, International Islamic University, Islamabad, Pakistan

${ }^{4}$ Electronic Section, British Malaysian Institute, Kuala Lumpur, Malaysia

${ }^{5}$ EME, NUST, Rawalpindi, Pakistan

Vibration and acoustic emission have received great attention of the research community for condition-based maintenance in rotating machinery. Several signal processing algorithms were either developed or used efficiently to detect and classify faults in bearings and gears. These signals are recorded, using sensors like tachometer or accelerometer, connected directly or mounted very close to the system under observation. This is not a feasible option in case of complex machinery and/or temperature and humidity. Therefore, it is required to sense the signals remotely, in order to reduce installation and maintenance cost. However, its installation far away from the intended device may pollute the required signal with other unwanted signals. In an attempt to address these issues, sound signal-based fault detection and classification in rotating bearings is presented. In this research work, audible sound of machine under test is captured using a single microphone and different statistical, spectral and spectrotemporal features are extracted. The selected features are then analyzed using different machine learning techniques, such as $\mathrm{K}$-nearest neighbor $(\mathrm{KNN})$ classifier, support vector machine (SVM), kernel liner discriminant analysis (KLDA) and sparse discriminant analysis (SDA). Simulation results show successful classification of faults into ball fault, inner and outer race faults. Best results were achieved using the KLDA followed by SDA, $\mathrm{KNN}$ and SVM. As far as features are concerned, the average FFT outperformed all the other features, followed by average PSD, RMS values of PSD, PSD and STFT.

\section{THE IMPACTS OF POLLUTION FOR NEW HIGH-SPEED RAILWAYS: THE CASE OF NOISE IN TURKEY \\ Yasin Sarikavak ${ }^{1,2}$, Alistair Boxall ${ }^{3}$ \\ ${ }^{1}$ Mechanical Engineering Department, Ankara Yıldırım Beyazıt University, Kecioren, Turkey \\ ${ }^{2}$ Railway Research and Technology Centre, Turkish State Railways, Ankara, Turkey \\ ${ }^{3}$ Department of Environment and Geography, University of York, Heslington, York, UK}

In recent years, high-speed train operations have been increasing, yet their environmental impact is still not well researched and understood. Evaluation of the impacts of
Turkey's new high-speed train lines from the perspectives of noise, vibration and socio-economic issues is important to secure sustainable development in the sector. National and international regulations are important to enable environmentally friendly railway systems to be secured. In this study, national and international regulations for the control of noise from conventional and high-speed train operations are reviewed and used to estimate distances which should not be exceeded for the Turkish high-speed train system. Calculated distances for EU and Turkish systems for noise threshold values of $87 \mathrm{~dB}$ (A) pass-by noise (LpAeq, $\mathrm{Tp}$ - measured $25 \mathrm{~m}$ distance from the centreline of the track and $3.5 \mathrm{~m}$ above the rail head), 65, 60 and $55 \mathrm{~dB}$ (A) (LpAeq, day; LpAeq, evening and LpAeq, night, the A-weighted average sound level for the specified time periods, at the most affected residential area, $4 \pm 0.2 \mathrm{~m}$ above the ground) were 28 , 160,272 and $469 \mathrm{~m}$ from the centreline of the track, respectively. These threshold distances were defined as a buffer zone in a railway map of Turkey in ArcGIS v.10.2.1 and merged with the Turkey population map to determine the population numbers which would be subjected to exposure above the threshold limits. Calculations conducted for highly populated cities showed that $2325,22,839$ and 3184 people would be exposed to railway noise exceeding the EU 96/48/EC Directive threshold limit $87 \mathrm{~dB}$ (A) for Ankara, İstanbul and İzmir, respectively. When calculations were repeated for the Turkey regulation threshold limits 65,60 and $55 \mathrm{~dB}(\mathrm{~A})$, these numbers were 10,767, 19,298, 35,951 for Ankara; 125,033, 210,360, 357,041 for İstanbul and $17,340,29,026,49,318$ for İzmir, respectively. The data indicate that some noise mitigation is required to protect human health in Turkey and potential mitigation strategies are discussed.

\section{ANALYTICAL MODELLING OF SOUND TRANSMISSION THROUGH FINITE CLAMPED DOUBLE-WALL PANELS WITH MAGNETIC-LINKED STIFFNESS}

Akintoye Olumide Oyelade

Department of Civil and Environmental Engineering, University of Lagos, Akoka, Lagos, Nigeria

A theoretical modelling approach is proposed for the vibroacoustic problem of sound transmission across a rectangular double-wall panel clamp mounted on an infinite rigid baffle with magnetically connected stiffness. The magnetic stiffness is derived based on interaction energy between the two rectangular magnets attached to the clamped plates.

The exact solution for the vibration of the clamped double plates is taken into account by the method of modal function, and the dynamic response of the structures is obtained by employing the weighted residual (Galerkin) method. This method enabled the coupling of the acoustic and the magnetic stiffness of the link to be done effectively. The accuracy of the theoretical predictions is checked against existing experimental data, with good agreement achieved. The model is then compared with the 
theoretical formulation in a duct based on a low-frequency range with and without magnetic stiffness. The sound transmission loss (STL) of the two models agrees perfectly in the first resonance, but the mass-air-mass resonance frequency for the current model tends to shift towards a higher value. Furthermore, the influence of magnetic stiffness on the elevation angle and azimuth angle of the STL is investigated. The present method is suitable for double-panel systems with connecting stiffness for practical plates and is applicable for both low- and high-frequency ranges.

\section{EFFECT OF ELEMENT FAILURES ON THE PERFORMANCE OF PASSIVE TOWED ARRAY SONARS}

Jojish V. Joseph, Niranjana Radhakrishnan, Sooraj K. Ambat

Naval Physical and Oceanographic Laboratory, Kochi, India

Linear towed arrays are one of the principal methods of underwater target detection, especially at low frequencies. A typical towed array contains many hydrophones in a flexible tube towed several hundred meters behind the ship. A practical problem in towed arrays is hydrophone or channel failures. Failed channels impact the side lobe levels and increase the leakage from tow-ship noise. This significantly affects the achievable figure of merit of the system. It is necessary to achieve quantitative assessments of the performance degradation to decide on the future course of action for maintenance or repair. In this paper, we propose a method to quantitatively assess the performance degradation of the sonar due to element failures. This method is capable of suggesting the operational envelopes of the platform which will still give acceptable performance under failed conditions. Simulation results and an online performance monitoring scheme are proposed, which will give in situ information on the performance degradation and sonar health. The experimental results with a linear array towed at different speeds and the corresponding degradation experienced due to element failures are also evaluated and found to match with the predicted results.

\section{NEAR-FIELD VARIATION OF LOUDNESS WITH DISTANCE \\ Zhushu Chen, Dongxing Mao \\ Institute of Acoustics, Tongji University, Shanghai, China}

The boundary element method was used to calculate the sound pressure levels at the two ears of an artificial head when a sound source was located in different directions and distances in the near field (within $1 \mathrm{~m}$ ). Total loudness was then calculated by using a binaural loudness model. Results showed that, in the near field, total loudness does not always increase monotonically as the source distance decreases. As distance decreased (for bands with center frequencies above $2 \mathrm{kHz}$ ), generally loudness first decreased and then increased (creating a local minimum); and when the distance became very small, the loudness generally began to decrease again (loudness had a local maximum). The external surface model of the artificial head was explored computationally. Calculations confirmed that the local minimum and maximum were caused by scattering from the shoulders. The effect of the width of the shoulders on near-field loudness was also determined. Finally, psychoacoustic experiments were conducted on four subjects. Results confirmed the presence of a local minimum and maximum and supported the idea that scattering from the shoulders was the main cause.

\section{DELVING INTO THE TWO-DIMENSIONAL STRUCTURE OF A COLD EDDY EAST OF TAIWAN AND ITS IMPACT ON ACOUSTIC PROPAGATION}

Cheng Chen ${ }^{1}$, Ya Gao ${ }^{2}$, Fenggang Yan ${ }^{1}$, Tao Jin ${ }^{1}$, Zhiquan Zhou ${ }^{1}$

${ }^{1}$ School of Information Science and Engineering, Harbin Institute of Technology, Weihai, China

2 Xi'an Keyway Technology Co., Ltd, Xi'an, China

A cold eddy was detected east of Taiwan. The twodimensional (2-D) eddy structure for the cold eddy was constructed with Argo data. Results show that the eddy structure follows that of an ellipsoid, where the largest anomaly occurs near the center at almost $400 \mathrm{~m}$ depth. The horizontal diameter was $200 \mathrm{~km}$, and the vertical diameter was $500 \mathrm{~m}$. The 2-D sound speed profile feature model for the cold eddy based on the Argo profiles was established with the EOF method. With the feature model, acoustic propagation through both a stationary eddy and a moving eddy was investigated. Results suggest that the presence of the cold eddy could push the convergence zone up to $4 \mathrm{~km}$ closer to the source, where it acts as a convex mirror to focus the energy. The movement of the eddy would affect the transmission loss of the first group ray arrivals by about $1 \mathrm{~dB}$, the time delay by about $0.01 \mathrm{~s}$, and the receiver angle by about $0.8^{\circ}$ when the source and the receiver were at $300 \mathrm{~m}$ depth and the receiver was located $300 \mathrm{~km}$ away from the source.

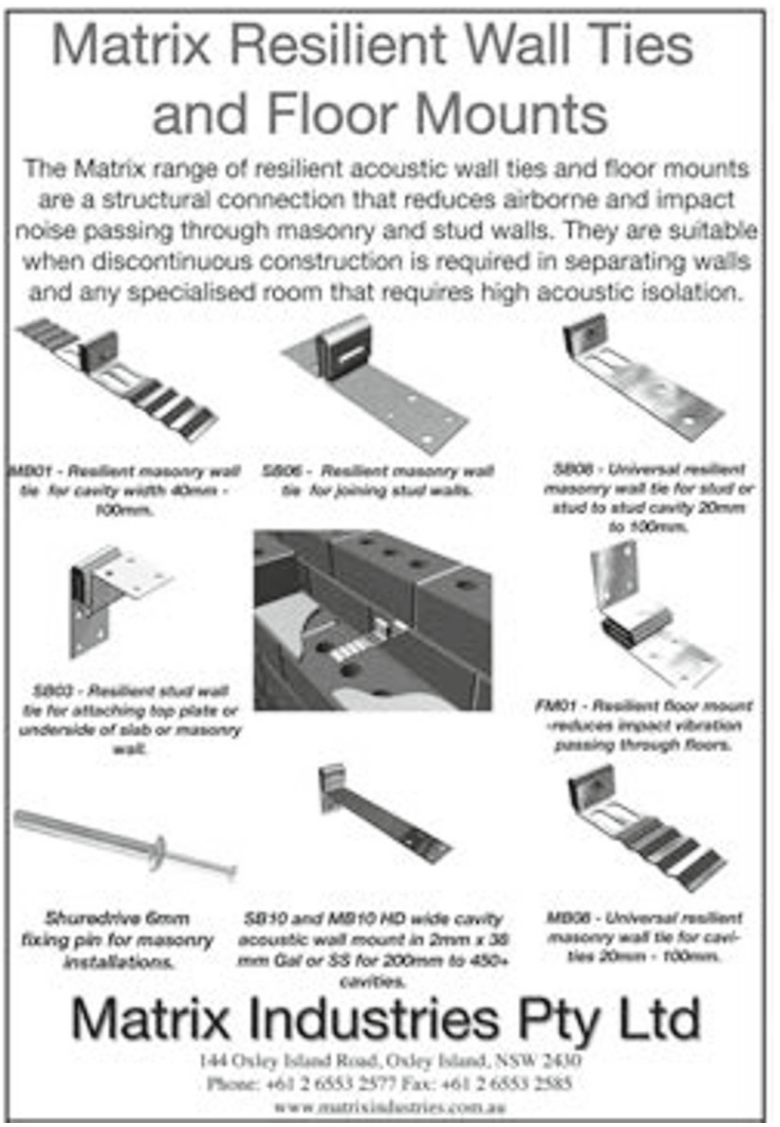



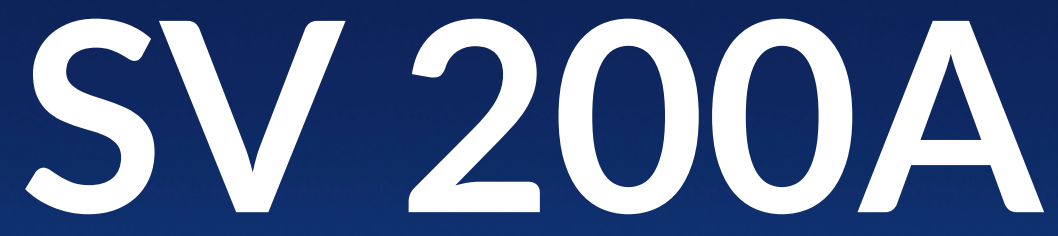

The only Noise Monitoring Station that detects the DIRECTION of a DOMINANT NOISE SOURCE both in the vertical and horizontal axis!

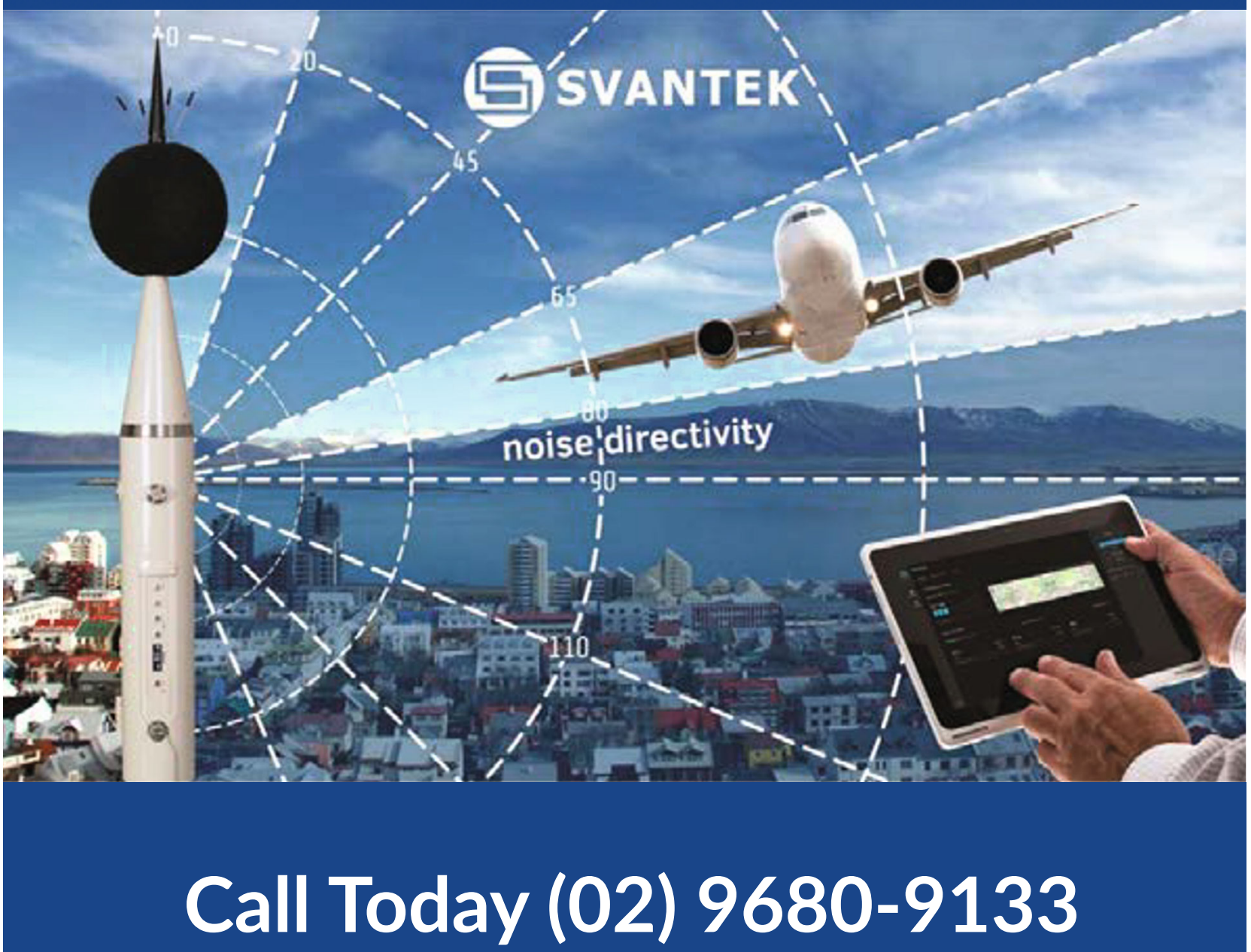

Acu-Vib Electronics

www.acu-vib.com.au

Unit 14/22 Hudson Ave CASTLE HILL 2154 


\section{NEWS FROM THE DIVISIONS}

\section{From the General Secretary}

It has been a busy start to the year and it's hard to believe we are halfway through already! Applications from new members have been regular and plenty resulting in AAS membership numbers growing steadily since my last report. Currently there are 729 AAS members including 24 sustaining members. VIC Division and SA Division have seen a steady growth in numbers and it's great to see the member base increasing in these states.

Membership figures are as follows:

NSW -332

VIC -162

QLD - 113

WA -81

$\mathrm{SA}-41$

Members have expressed that work has been keeping them very busy since the beginning of the year and as a result the deadline for submissions for the Research Grant has been extended to accommodate the time pressed member base. The revised deadline for submissions was 31 st July 2019 and the quality of submissions received is high. I encourage you to apply for the Research Grant or the Education Grant as this funding is an opportunity too good to miss. The deadline for the Education Grant also was the 31st July 2019.

Annual membership fees were sent out in late April and I am pleased to report that most members paid their fees promptly. As a 'Not for Profit' organisation, the majority of funds collected are redistributed to members through grants, education, awards and the provision of resources to the member base. Members that pay their fees on time are assisting the AAS to continue to function in a consistent capacity. The AAS often receives calls from the media and the general public seeking qualified acousticians and expert advice. As the field of acoustics encompasses a multitude of industries and areas of study it is an immeasurable asset to have the variety of experts and wealth of knowledge that is contained within the Society available to those that require assistance and advice.

I have been spending time delving into the Society archives and it has been an interesting journey. It has offered great insight into the formation and objectives of the AAS. Seeing the progression of the AAS forming as a small group of like-minded professionals wanting to do more for their field and having it progressively bloom into the thriving Society today is a remarkable achievement.

The 2019 conference in Cape Schanck is gearing up and I am looking forward to catching up with members at the event. I will be in attendance for the duration of the conference so if you have any enquiries or you would just like to say hello, please do not hesitate to find me. Tickets are selling fast and accommodation is booking out, so get in now to ensure you don't miss out on this great event. Finally, it is with great sadness that I reflect upon the passing of Richard Booker. Richard was a kind and generous man that dedicated over a decade to the AAS. I feel honoured to not only have had the opportunity to know him, but to follow in his footsteps. The memorial service held in Brisbane was well attended by AAS members paying their respects to Richard and his family. Richard will be missed, but not forgotten.

\section{NSW Division}

Julie Sobolewski, General Secretary

The NSW Division has again been fortunate to continue to attract a number of great speakers for our Technical Talks. In April, we welcomed Associate Professor Tara Hamilton who is with the School of Engineering at Macquarie University and the MARCS Institute at Western Sydney University.
Tara gave an overview of over 30 years of progress developing models of the cochlea and auditory perception. She also touched on the progress that has been made to hearing technologies: cochlear implants, hearing aids, Siri, Google, Alexa, and many others.

In July we had two talks, firstly covering aircraft noise modelling and the proposed use of the United States Federal Aviation Administration (FAA) Aviation Environmental Design Tool (AEDT) in the technical endorsement process of assessing airport noise by Mark Latimore of Airservices Australia, followed later in the month by an international visitor from Ireland, Diarmuid Keaney, who kindly provided us with some insights and perspectives of how noise control and management are approached in the UK.

Finally, it's that time of year when the NSW Division also recognises the best final year university students. First off was Anna Hawkins from Audiology and Hearing, Department of Linguistics, Macquarie University, followed by Tim Davis at the University of New South Wales who were each awarded the Australia Acoustical Society (NSW Division) Prize, while at Western Sydney University Raneen Yaseen and Venus Savaliya were awarded the AAS NSW Division Vibration Prize.

Angus Leslie

\section{WA Division}

The WA Division are again preparing to host a one-day WA AAS State Seminar / AGM to be held in October 2019. This casual oneday event allows members to catch up and discuss current issues and opportunities to improve the science and practice of acoustics.

Any WA members who wish to present may contact the WA Division Committee. Further details will be e-mailed to members in due course.

Luke Zoontjens
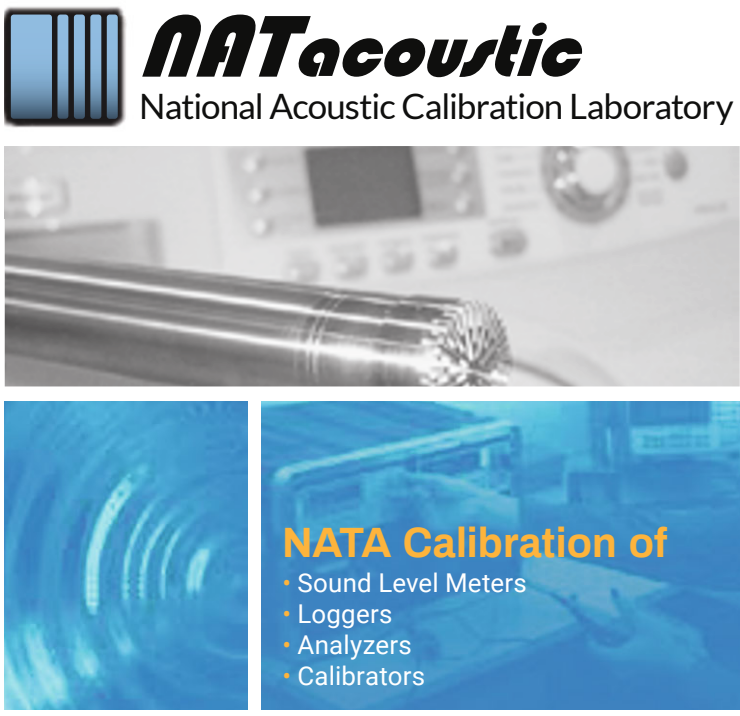

We Calibrate All SLMs \& Calibrators

\begin{tabular}{|c|c|c|}
\hline $\begin{array}{l}\circ \text { B \& K } \\
\text { - Norsonics } \\
\text { - Rion }\end{array}$ & $\begin{array}{l}\text { - ARL } \\
\text { - RTA Technology } \\
\text { - Svantek }\end{array}$ & $\begin{array}{l}\text { - Larson Davis } \\
\text { - Cesva } \\
\text { - CEL }\end{array}$ \\
\hline
\end{tabular}

$\circ$ Rion
$\circ$ NTI
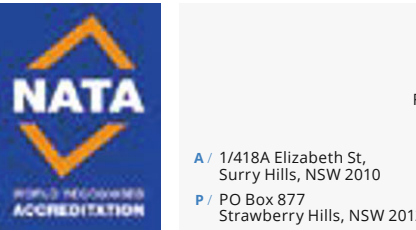

NATacoustic

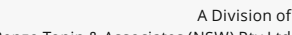
Renzo Tonin \& Associates (NSW) Pty Ltd ABN 29117462861 (02) 82180570 service@natacoustic.com.au / natacoustic.com.au 


\section{ACOUSTICS NEWS}

\section{I-INCE 2019 General Assembly}

The 2019 General Assembly meeting of the International Institute of Noise Control Engineering (I-INCE) was held on 16 June 2019 in Madrid, Spain immediately before the start of the Inter-Noise 2019 congress. John Davy was the representative of the Australian Acoustical Society.

The President, Marion Burgess called the meeting to order. After the roll call of member societies (over 40) a summary of the activities was given. Patricia Davies delivered the Technical Activities report. The Pre-Future Congress Technical Planning (FCTP) meeting continues to be held on Sunday morning before the congress. The FTCP meeting is being held over lunch on the final day of the congress to avoid conflict with technical sessions. There were 20 Young Professional Awards this year. Member societies are encouraged to send out information on these awards to young professionals. The I-INCE Practice of Noise Control School ("Sunday School") was held on Sunday. There were four 45-minute presentations for young professionals. The young professional awards were presented on Monday afternoon. There was also a workshop with an overview on writing, editing and getting published, and two panel discussions on "Being a faculty member" and "Networking and tips for job creation". There are currently no active Technical Study Groups (TSG), but TSG10 "Buy Quiet" has just submitted its report.

The 2020 Inter-Noise will be held in Seoul, Korea and the 50th anniversary Inter-Noise 2021, will be held in Washington, DC, USA where the first Inter-Noise was held. In 2022 Inter-Noise will be held in the Europe-Africa region, 2023 in the Asia-Pacific region. In 2024, there will be a change to the rotation order to avoid the Inter-Noise congress being held in the Europe-Africa region in the year when the International Congress on Acoustics (ICA) is held. In 2024, InterNoise will be held in the Europe-Africa region and in 2025 will be held in Pan America.

At the beginning of 2020, Robert Bernhard will become President, Luigi Maffei will become President-elect and Marion Burgess will become Past-president. Paul Donavan and Douglas Manvell will continue as Secretary-general and Treasurer. Gijsan van Blokland will become Vice-president of development and outreach. Antonio PérezLópez, the President of Inter-Noise 2019, will become a Director. Otto von Estorff and Joachim Scheuren will become Distinguished board members.

There was an election for an Asian-Pacific Director-at-large. The candidates were Kang-duck Ih from Korea, Jun Yang from China and John Davy from Australia. The successful candidate was John Davy who was nominated by the Australian Acoustical Society.

The Treasurer, Douglas Manvell, presented the audited accounts. For 2020 Norm Broner from Australia has agreed to be the auditor.

Members of the Congress Selection Committee (CSC) are elected for three years and can serve for a maximum of two terms. Jun Yang had served for two 3 year terms as a representative for the Asia-Pacific region and was not eligible for re-election. The Australian Acoustical Society's nominee, John Davy, was elected unopposed to replace him. Davii Ackermann is now a member of the CSC as the Vice-president for Pan America. Thus, his former position as a Pan American representative has been filled by Joe Cuschieri.

Antonio Pérez-López reported on Inter-Noise 2019. There were 894 papers which consisted of 815 oral presentations and 79 poster presentations. These papers had 2,925 authors. There were 883 full registrations and 270 student representations, giving a total of 1153 technical registrations. There were also 53 accompanying person registrations.

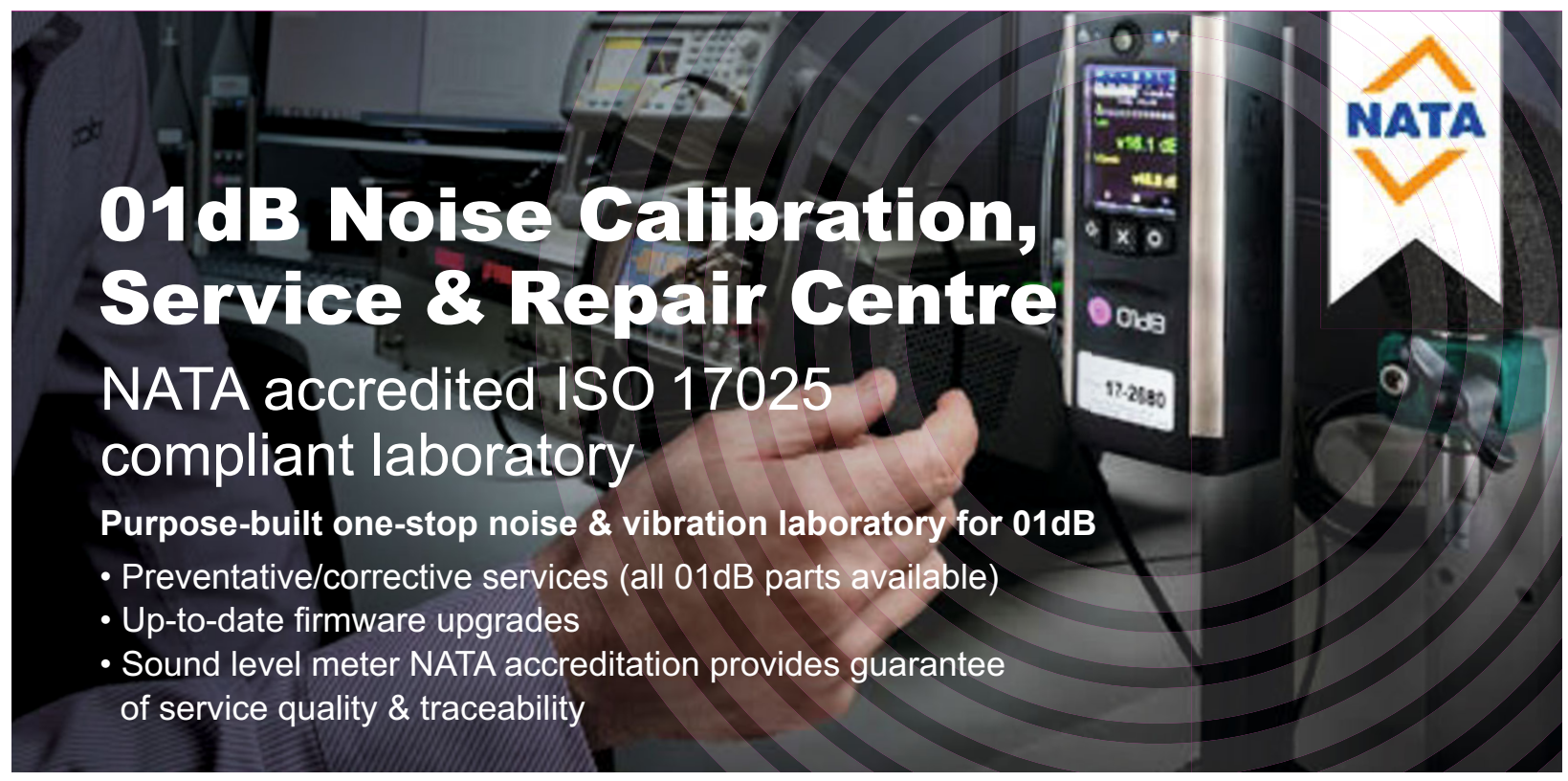

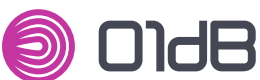

ACOEM Group

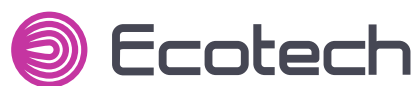

ACOEM Group
1300166497 | calibrations@ecotech.com ecotech.com/01dB-csr-centre 
There were registrations from 51 countries. The most registrations were from Spain $12 \%$, China $11 \%$, Japan $8 \%$, Germany $8 \%$ and South Korea $8 \%$. The biggest theme areas were Architectural and Building Acoustics, 147 papers, Environmental Noise, 120 papers, Vehicle Noise, 83 papers, and Vibro-acoustics, 83 papers. There were 55 exhibitors, 61 companies and 64 booths. There were two workshops for which there were 100 registered attendees, but only about 20 people actually attended. There were two short courses, but one was cancelled and the other one had 7 participants. There were six other meetings held during the conference and four plenary lectures.

The 49th Inter-Noise will be held in Seoul, Korea from 23-26 August 2020. 1000 participants are expected. The abstract submission deadline is 15 March 2020 and the paper submission deadline is 15 May 2020. The congress will be held at Coex which is $66 \mathrm{~km}$ from Incheon Airport. The shuttle bus takes 1 hour to make the journey. There 27 hotels with 6,000 rooms in total. Coex has Asia's largest underground shopping centre. The congress will have 19 technical areas.

The 50th Anniversary Inter-Noise will be held at the Marriott Hotel in Washington, DC, USA. It will be jointly hosted by the USA and Brazil. The co-chairs are Jim Thompson and Davii Ackermann. There will be a full one-day session organized by the Pan American member societies. There will be a reception instead of a conference banquet. There will also be short courses, a practice school and a young professionals workshop.

The International Year of Sound will be held in 2020. The web site is www.sound2020.org. It is being run by the ICA and La Semaine du Son. The aim is to have outreach events such as public lectures. Events will be posted on the web site. The opening will be at the Sorbonne University in Paris, France. There will be a schools' competition and a short film will be ready by the first week of January 2020. I-INCE wants to sponsor activities for the International Year of Sound.

Joe Cuschieri is the Vice-president for Communications and is also the Web master. Eoin King is the editor of NNI which is now published quarterly as a blog and as a pdf file. NNI has 41 followers on Facebook, 120 followers on Twitter and 77 followers on Instagram. Its Twitter handle is @NNIeditor. I-INCE wants member societies to try and increase the number of followers. There are rotating editorials from the different I-INCE Vice presidents. NNI needs help to find advertisers. Advertisements will be published in both the blog and the pdf version. The past congress proceedings are available on the I-INCE Digital Library. All member societies have free access.

The next meeting will be held on the Sunday afternoon immediately before Inter-noise 2020 in Korea.

John Davy

\section{Noise - does it have a future?}

There's evidence of a broader societal change in the way in which people think about sound and their relationship to noise.

Notions about what constitutes wanted and unwanted noise can be enormously subjective. Since 2007, Dr Bruce Fell, a lecturer in Communications at Charles Sturt University, has been studying the way in which his undergraduate students relate to the sound of technology. 'The sound of the media is part of what they would call their natural environment,' says Dr Fell. 'The vast majority of my students were born in urban environments where that [the sound of technology] is the dominant sound in their lives. To them a natural environment is an environment in which there is a television in the background, and they talk about their mums and dads or even grandparents always having the television on, it has always been on in their life.'

Extract from article published by Antony Funnell at:

https://www.abc.net.au/radionational/programs/futuretense/noisedoes-it-have-a-future/5237628

Darren Jurevicius

\section{NCC to be adopted by all States and Territories}

From 1 May 2019, the 2019 edition of the National Construction Code (NCC) is given legal effect by relevant legislation in each State and Territory.

If you missed hearing about the changes contained in NCC 2019 at the Australian Building Codes Board's (ABCB) recent 2019 NCC Seminars, you can now watch the webcasts, including an additional webcast on the Plumbing Code of Australia.

More information: https://ncc.abcb.gov.au/ncc-online/NCC

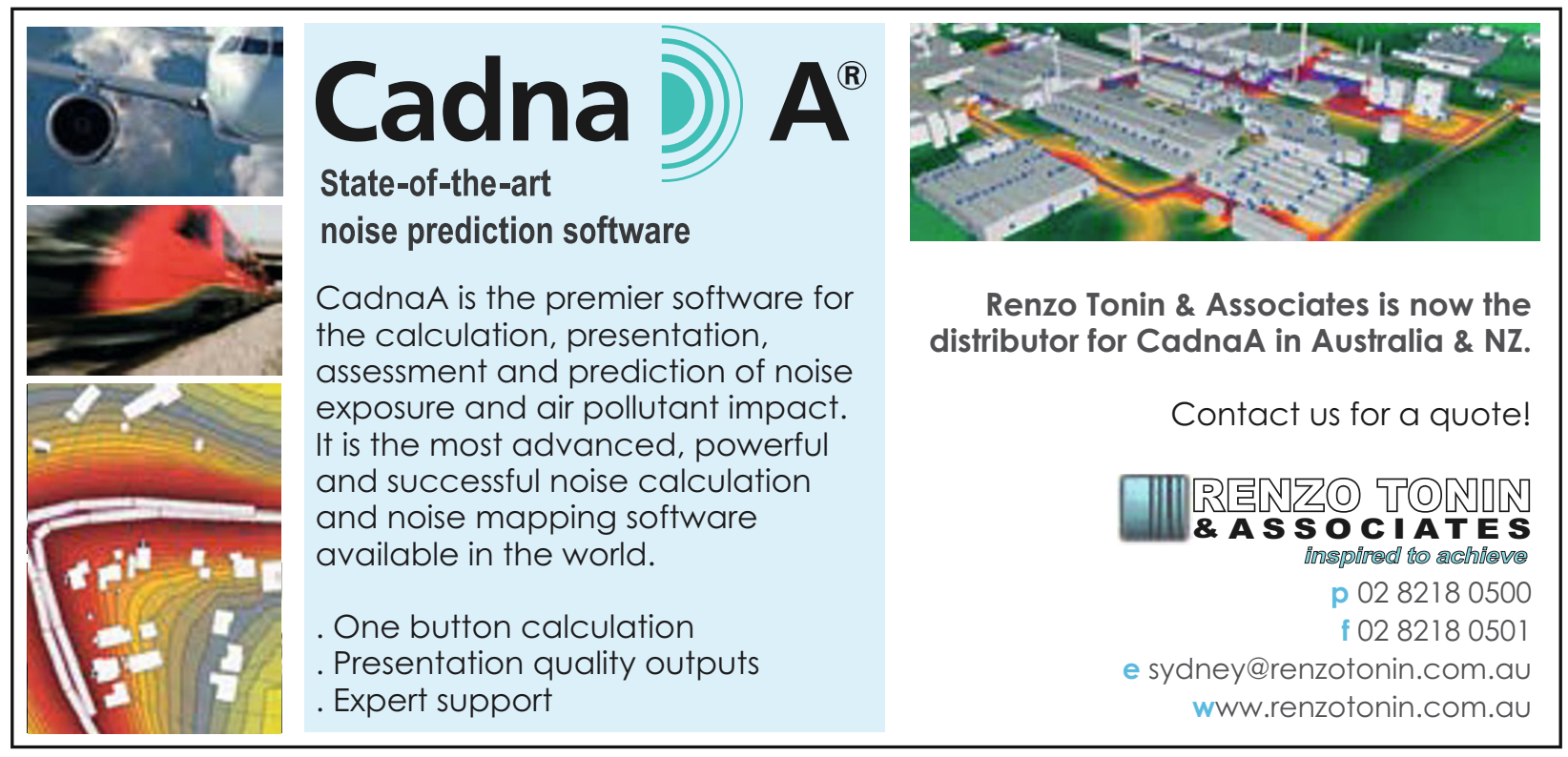




\section{- OBITUARY -}

\section{Richard Booker 1949 - 2019}

On the 22nd May 2019 the Acoustical Society lost a Member who, as General Secretary over a period of eight years from 2010, helped to transform the administration of the Society by updating and improving the membership database, invoicing and other systems. While Members knew Richard as the person charged with ensuring that the Society functioned in an organised manner, his lifetime of experience with people from all walks of life, different backgrounds and professions enabled him to project a professional image for the Society, while being friendly, personable, patient and helpful to Members.

Richard Booker was born in 1949 in Christchurch, New Zealand. When very young, his family moved to Lower Hutt (near Wellington) where Richard spent his primary and secondary years. In the early 1970s, he travelled to Western Australia and the mines, returning to New Zealand to study philosophy and architecture at Auckland University, with surfing a big part in his life. In the mid-to-late 1970s, Richard studied ceramics at the Otago School of Fine Arts before setting up his own pottery studio. In the 1980s, he left New Zealand and travelled across Asia to Europe, finally settling in Spain where he taught English for three years. Towards the end of that decade Richard returned to Sydney where he set up business designing, screening printing and hand painting ceramic tiles for domestic and commercial use. During the operation of his business, Richard discovered the Apple Macintosh and the copy, cut and paste function which revolutionised his tile designs.

At the end of the 1980s Richard embarked on a different career path, putting his computer skills to good use whilst working for the NSW Education Department and Optus. In those roles he honed his technical writing, refined his IT skills and became accustomed to working as part of teams tasked with delivering complex projects on time and budget. In 1999 Richard moved to Dubai in the United Arab Emirates as IT manager for the University of Wollongong (Dubai) before returning to Australia and Brisbane when his wife, Phillipa, commenced a role at the University of Queensland.

In July 2010, Richard became the General Secretary of the Australian Acoustical Society on the recommendation of his close friend Colin Speakman. Inheriting an outdated membership database and billing system, Richard used his IT skills, patience and attention to detail to update and improve our systems, resulting in a greater proportion of on-time membership payments, greater accuracy in tracking data and reporting. Naturally curious and with a keen desire to continually be learning and growing, Richard never shied away from challenges, always striving to find solutions to problems as they arose, with the goal of improving and creating efficiencies to existing systems and processes.
Within Federal Council, Richard's diligence and organisation was greatly appreciated. His quiet urbanity, patience and diplomacy were major assets in the sometimes-fractious debates that characterise our meetings. At conference dinners, and in Divisional technical meetings, Richard could always be relied upon for a good yarn on any topic - his dry but lively sense of humour to the fore.

Even as his health began to decline, Richard remained motivated and committed to upholding and progressing the aims, aspirations and Charter of the Society. His retirement in October 2018, while expected, was met with sadness by Federal Council and Members. Richard was a standout in the role of General Secretary and as such, Honorary membership was bestowed on him in December 2018.

In retirement and wanting to keep himself busy, he rediscovered his passion for ceramics and joined Clayschool in West End, Brisbane. A lover of fine food and wine (particularly red wine), debates and conversation, books, politics, current affairs, travel, art, movies, photography, computers, design and gardening, Richard formed many bonds and friendships with Members. His influence will be long-lasting, not only through the improvements to governance and functioning of the Society which he wrought, but also through his influence on every person who was fortunate to meet and work with him and be touched by his dignity, diligence, ethics, persistence and friendliness.

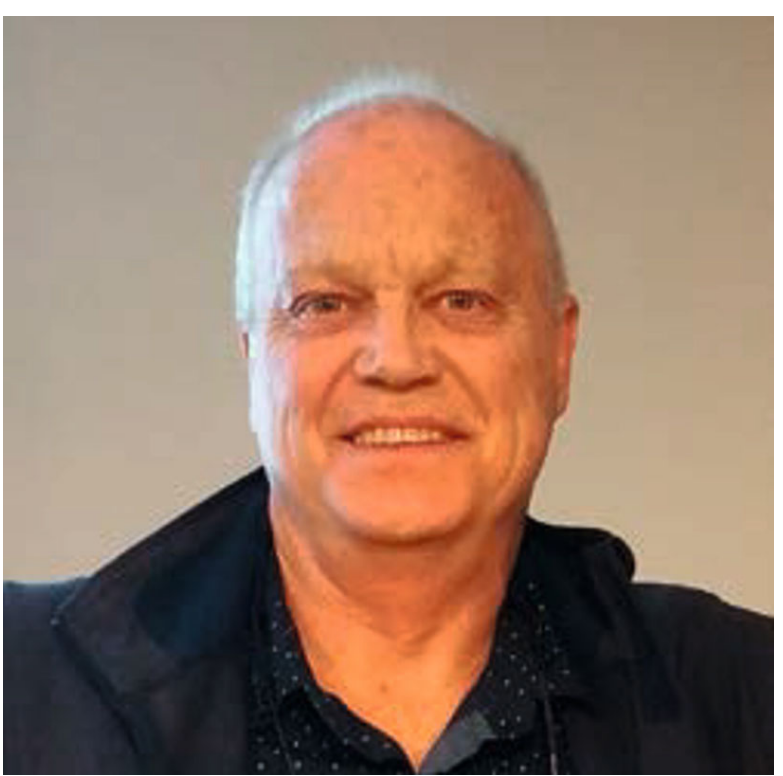




\section{- OBITUARY -}

\section{David Rennison 1949 - 2019}

David Rennison passed away on 20 June 2019 at the age of 70, after a long and courageous battle with cancer.

David became a member of the AAS in 1976 and was a leading acoustic engineer and consultant for over 40 years, particularly renowned as a world leader in the field of vibro-acoustics and engineering dynamics. After a PhD in acoustics at Adelaide University in 1977, he worked at Bolt Beranek Newman engineering firm in the USA doing groundbreaking studies for NASA on the aerodynamics and vibration response of the Space Shuttle.

David returned to Australia in 1980 and joined Vipac Engineers \& Scientists Ltd. David was an integral and influential part of Vipac for 35 years (based in the Adelaide office) as a Principal Engineer, Manager and Director, and helped build Vipac into a leading and reputable engineering consultancy company. He was always pushing the boundaries, trying to be ahead of the curve and lead by example, and was known for the epithet "one more test Rennison"! David's energies were often directed towards visionary and innovative ideas, many of which were developed into world leading developments and products.

David was instrumental in building up and leading the successful Trackside Intelligence (Track IQ) group, where David's vision was to invent and develop the most advanced and effective rail vehicle diagnostic acoustic sensor system in the world, which he led and drove to fruition. David moved with the group when it was purchased from Vipac by US company Wabtec in 2015, and at the time the group had over 100 installations in 14 countries across 6 continents.

As many of his colleagues can attest, David had a remarkable intellect, passion and drive, yet was very humble, generous and had a great sense of humour among other qualities.
He was down to earth and did not make a big noise about himself, which was appropriate for a noise control guy! David accomplished so much in a long, distinguished career including numerous technical advances, publications and awards. Importantly, he was such a valued and inspirational mentor, motivator and leader for so many acousticians and engineers over the years... a remarkable legacy.

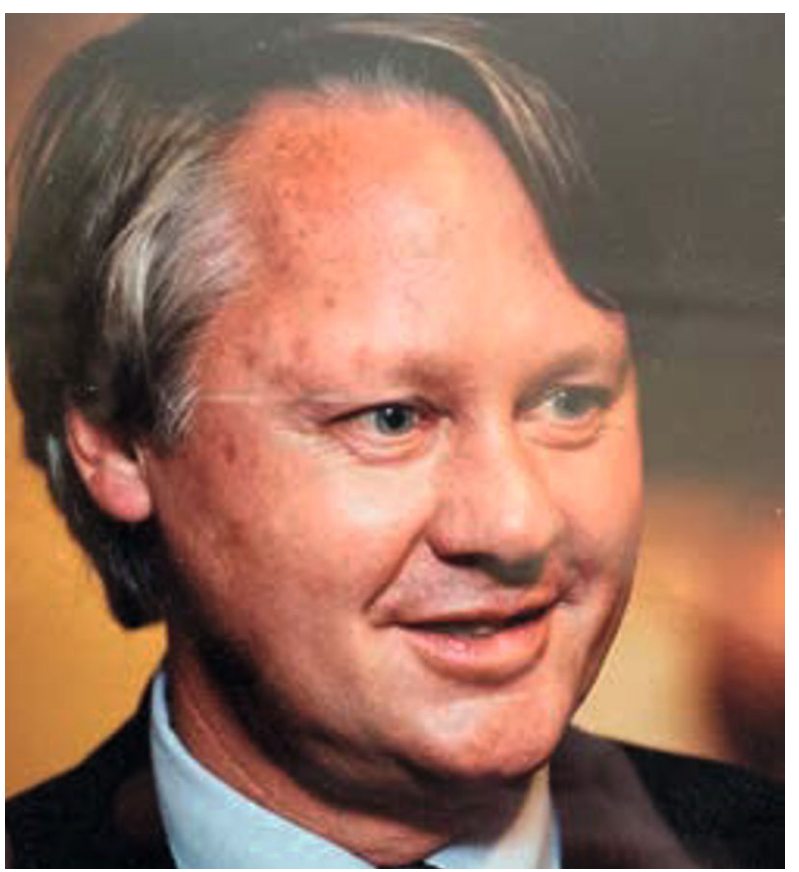




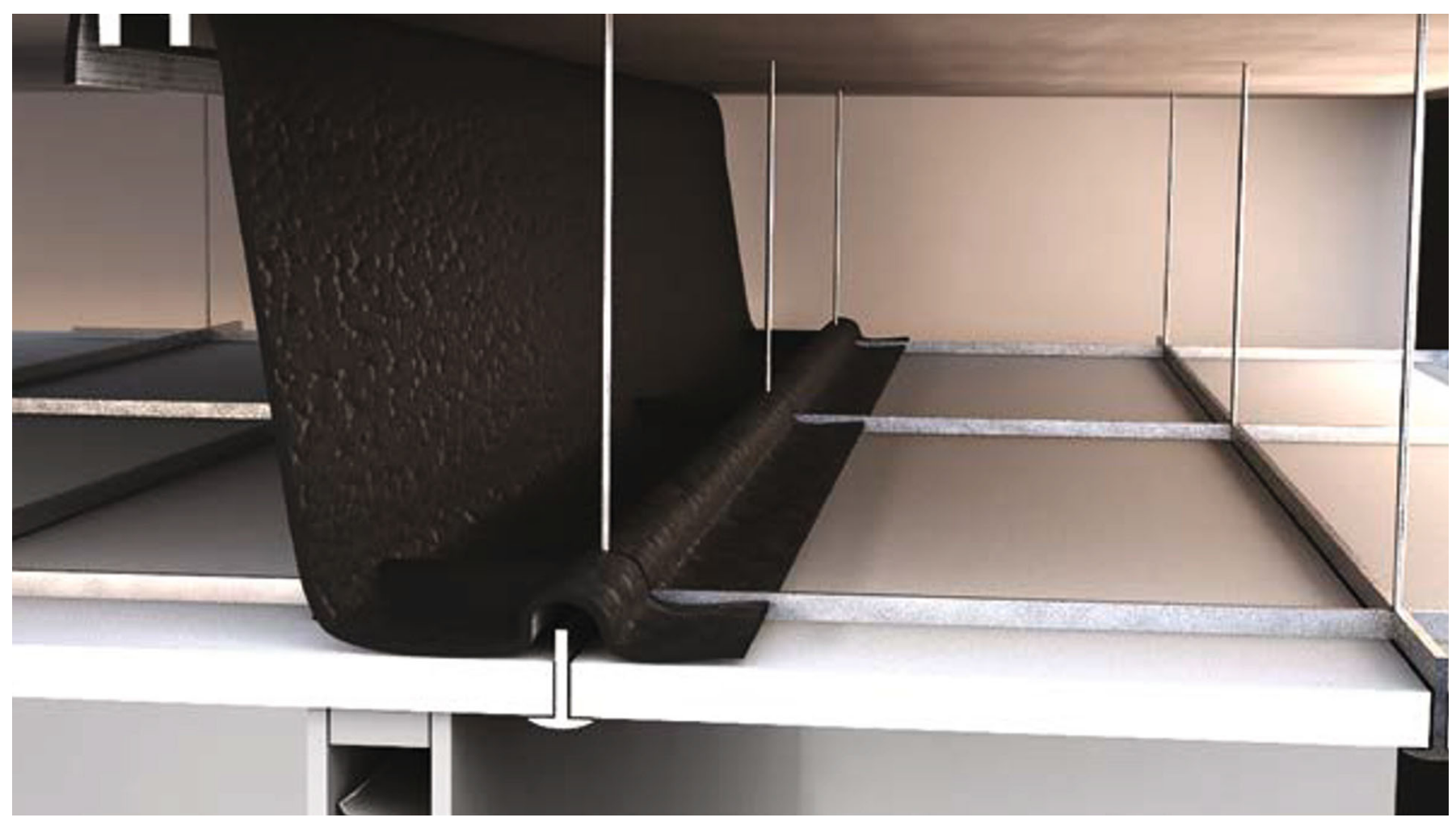

\section{Wavebar ${ }^{\circledR}$ superior transmission loss}

Pyrolek.

pyroteknc.com
Address noise transfer in commercial, residential and office buildings with Wavebar ${ }^{\circledast}$

Wavebar can reduce the transmission of noise between walls, floors or ceilings of adjoining rooms. With the thin, dense,

highly-flexible and tear-resistant properties, Wavebar achieves high-performance results.
- Ceiling plenums

- Seismic joints

- Wall penetrations

- Power sockets
- Window mullions

- Access hatches

- HVAC penetrations

- Light fittings 


\section{ACOUSTICS FORUM}

\section{SIMPLE REVERBERATION TIME SPECIFICATIONS - A TRAP FOR THE UNWARY}

Peter Patrick

Scientific Acoustics, Bauple, Australia

info@scientific-acoustics.com.au

\begin{abstract}
Green Star building requirements, (1) apply 1 point of credit where reverberation time, for a dedicated teaching space that has reverberation time "below the maximum stated under 'Recommended Reverberation Time' provided in Table 1 of AS/NZS 2107: 2016". Apart from requiring on site measurement, the Green Star document allows further that "Alternatively, compliance may be demonstrated by treating $50 \%$ of the combined floor and ceiling area with a material having a NRC of at least 0.5." The author followed this approach for a small Eco Classroom of some $409 \mathrm{~m} 3$ by treating approximately 111 $\mathrm{m} 2$ of a total $211 \mathrm{~m} 2$ ceiling with a product carrying an NRC rating of 0.95. Initial on-site tests showed that the objective from AS/NZS 2107 was well out of reach. The shortcomings of the simple approach in the Green Star document are discussed here.
\end{abstract}

\section{Initial modelling}

The classroom was modelled in EASE 4.4 acoustic software (http:// ease.afmg.eu/) in rough outline given that the objective is noise control rather than specialised auditorium characteristics. The wire frame model is shown in Figure 1 below with wall height $3.0 \mathrm{~m}$, length $12.5 \mathrm{~m}$ and width $8.0 \mathrm{~m}$.

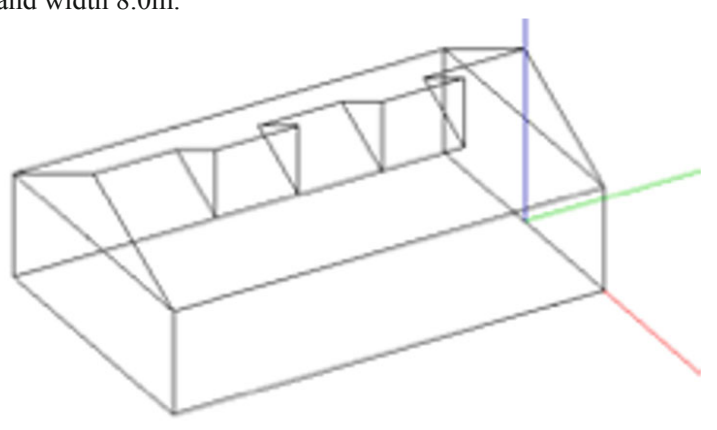

Figure 1. Initial Wire frame model

Section 5.4 of AS/NZS 2107:2016 (2) describes the measure of recommended reverberation time as the arithmetic average of the reverberation times in the octave bands at $500 \mathrm{~Hz}$ and $1,000 \mathrm{~Hz}$. EASE software calculated that the reverberation time of the space would be 0.55 seconds and 0.56 seconds at $500 \mathrm{~Hz}$ and $1,000 \mathrm{~Hz}$ respectively (using Sabine's formula.) An examination of Curve 3 in AS/NZS 2107:2016 (2) gave 0.66 seconds as the recommended reverberation time for a single classroom of $409 \mathrm{~m} 3$. Clearly the use of a $40 \mathrm{~mm}$ Fibreglass tile on the ceiling, NRC 0.95, was effective, at least from a design perspective.

On site measurements were made with a Larson Davis Model 824, class 1 , sound level meter. The reverberation times were determined in terms of T20, using a $20 \mathrm{~dB}$ decay rate, which is more attainable in field measurements. The initial measurement data gave T20 of 0.99 and $0.91 \mathrm{sec}$ at $500 \mathrm{~Hz}$ and $1,000 \mathrm{~Hz}$ respectively. It was clear that a more detailed analysis of the room model was required.

\section{Detailed modelling}

The Ease model was updated to include glass and cupboards as shown in figure 2. Properties such as scattering were included in materials according to estimated effect related to size. The AURA hybrid ray trace routine was then run to derive a more accurate picture of the room's behaviour. It is worth noting here that the real life 'as built' room under test had no other furnishings, floor was bare smooth concrete and all other fittings such as ceiling fans were in place. The initial test run in the model, using AURA, predicted T20 readings of 0.87 seconds at both $500 \mathrm{~Hz}$ and $1,000 \mathrm{~Hz}$. A re-run of the same hybrid ray trace routine with the same, $40 \mathrm{~mm}$ thick, fibreglass product used on the ceiling, added to cover the entire floor, produced T2 0 readings of 0.73 seconds and 0.82 seconds at $500 \mathrm{~Hz}$ and $1,000 \mathrm{~Hz}$ respectively. In this condition the Sabine calculation delivered 0.41 seconds at both $500 \mathrm{~Hz}$ and $1,000 \mathrm{~Hz}$.

A further comparison was made between the two prediction options, with additional sound absorption over the entire floor. The use of the AURA gave T20 readings of 0.73 and $0.82 \mathrm{sec}$ at $500 \mathrm{~Hz}$ and 1,000 $\mathrm{Hz}$ respectively and the Sabine method $0.41 \mathrm{sec}$ at both $500 \mathrm{~Hz}$ and $1,000 \mathrm{~Hz}$.

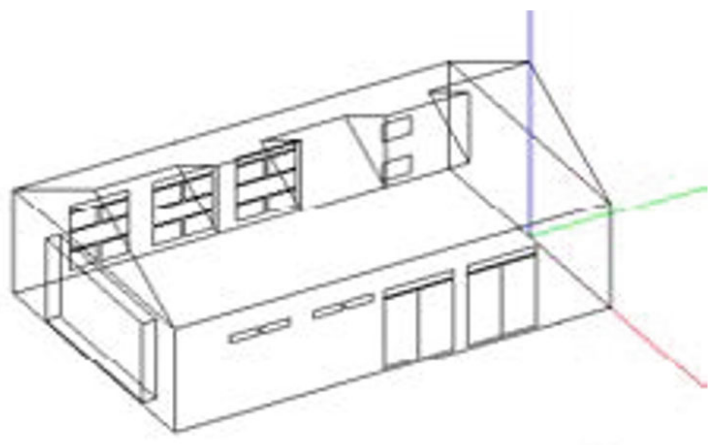

Figure 2. Wire Frame of detailed model

\section{General discussion}

The author is well aware that placing all of the acoustic absorption on one plane of a 3-D space has demerits. On the other hand, there is also a general 'rule of thumb' which implies that this arrangement is acceptable if the only required outcome is noise control. Indeed, the text in the Green Star document allowing for $50 \%$ of the combined floor/ceiling area to be treated with material rated at NRC 0.5 , aligns with the 'acceptable for noise control' proposition. However, the ratio of floor to wall dimension and the smooth nature of wall surfaces in the Eco classroom conspired to highlight the shortcomings of this approach. In many rooms, diffusion produced by furniture and 'bric-a-brac' scattered about can obscure the shortcomings of the generalised approach.

\section{Meeting the target}

Closer examination of the Green Star document revealed that the room under test should be set as for normal operation of the classroom. This requires that since the space is not air conditioned, the windows be open. Following this line of reasoning the windows (some $11 \mathrm{~m} 2$ open area.) and a random selection of cupboard doors opened. Finally, 24 student chairs were placed at random on the floor. Table 1 and Figure 3 give measured data for 3 different room configurations. Figure 3 below that gives the same information in graphical form. The effect of the combined scattering and absorption from open cupboards, open windows and twenty-four student chairs is very clear. 


\begin{tabular}{|l|l|l|l|l|l|l|}
\hline Octave Band & $125 \mathrm{~Hz}$ & $250 \mathrm{~Hz}$ & $500 \mathrm{~Hz}$ & $1,000 \mathrm{~Hz}$ & $2,000 \mathrm{~Hz}$ & $4,000 \mathrm{~Hz}$ \\
\hline Real Room as built, initial Measurement & 1.07 & 1.06 & 1.01 & 0.95 & 0.86 & 0.74 \\
\hline Real Room as built with open cupboards & 0.84 & 0.92 & 0.85 & 0.86 & 0.84 & 0.77 \\
\hline $\begin{array}{l}\text { Real Room final test with open cupboards, } \\
\text { open windows and 24 students' chairs }\end{array}$ & 0.61 & 0.63 & 0.58 & 0.58 & 0.62 & 0.57 \\
\hline $\begin{array}{l}\text { Recommended in AS/NZS 2107 (Arithmetic } \\
\text { average shown in both columns) }\end{array}$ & & & 0.66 & 0.66 & & \\
\hline
\end{tabular}

Table 1. Octave band measured values for T20 for various room conditions.

Measured Reverberation Time in Octave bands

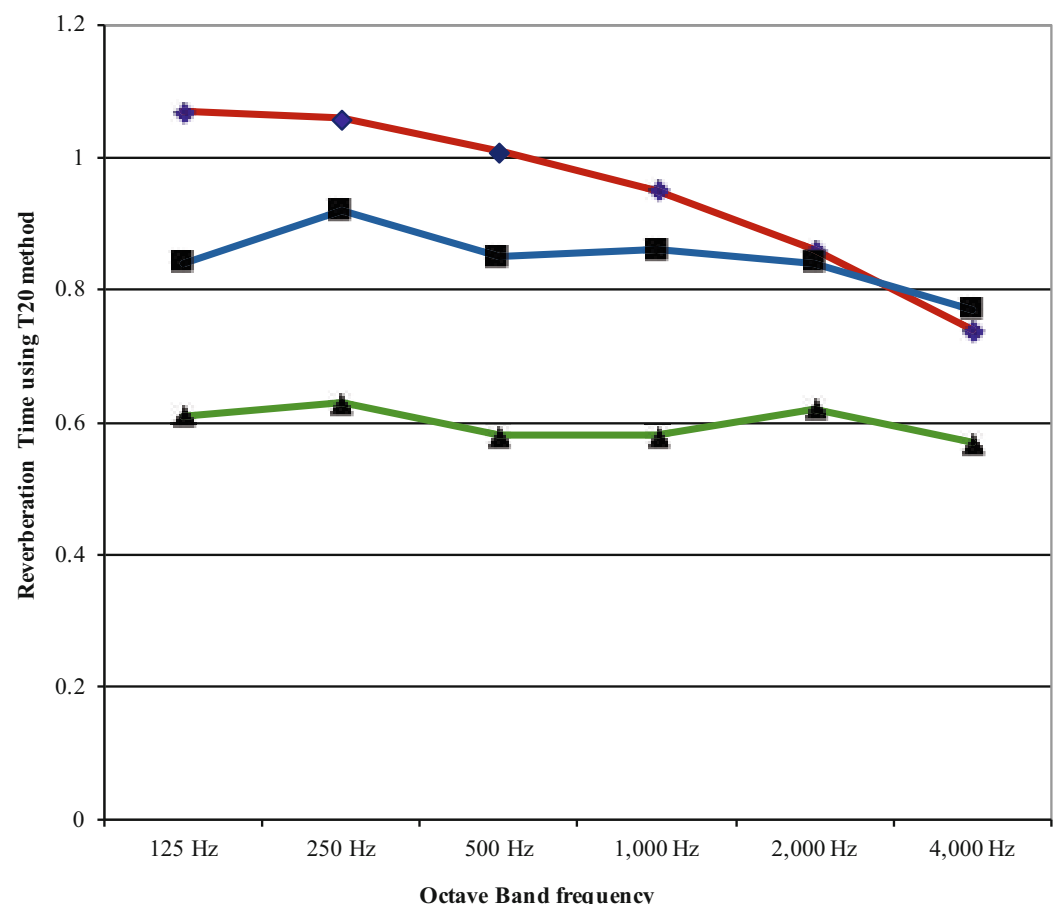

Figure 3. Graphs of T20 for various room conditions

The measured value for $\mathrm{T} 20$ for $500 \mathrm{~Hz}$ and $1,000 \mathrm{~Hz}$ is 0.57 seconds. The open windows added approximately $11 \mathrm{~m} 2$ of absorption. This changed the average absorption coefficient of the room from 0.32 to 0.35 . Thus, in a room consisting of $368 \mathrm{~m} 2$ surface area, by adding $3 \%$ surface area of absorption, and a deal of scattering, the T20 value has been reduced by around $40 \%$. The final test conditions are shown in Figure 4.

\section{Conclusion}

The author resolves never to trust a simplified "Noise Reduction" approach to reverberation control again. W.C. Sabine worked in spaces in which the absorption was apparently reasonably evenly distributed thereby the well known equation was derived. Others (Eyring, Fitzroy, Millington-Sette et al.) have since noted shortcomings and offered alternatives. Nonetheless the human penchant for single digit descriptors of complex concepts prevails whereby we continue to see NRC ratings used extensively to describe acoustic absorbers and applied in general terms to enclosed spaces. The belief in such an approach, as shown in the Green Star document, leaves one wondering just what is the success rate of these specifications and, if the experience reported here is as common as seems likely, why do we persist with such flawed documentation?

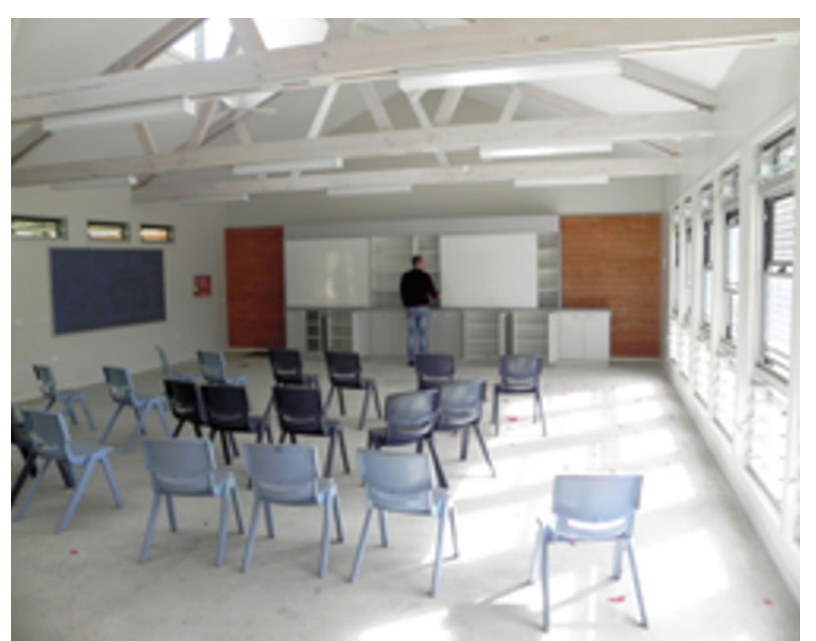

Figure 4. Photograph of classroom under final test conditions.

\section{References}

${ }^{1}$ Green Star- Design \& As Built v1.2 10 Acoustic Comfort,

${ }^{2}$ AS/NZS 2107:2016 


\section{NEW PRODUCTS}

Environmental Monitoring Units hear noise and feel vibration

EMS Brüel \& Kjaer announces the release of the EMU Environmental Monitoring Unit. Capable of measuring noise, vibration, weather and blast overpressure simultaneously, the EMU combines everything needed for continuous measurement, accessed remotely in real time in a single unit. The unit incorporates sensors, data logger, cellular and Wi-Fi communications and battery in a tough waterproof enclosure, the fully integrated solution makes it very simple to use.

More information:

https://www.emsbk.com/environmental-monitoring-unit-3/

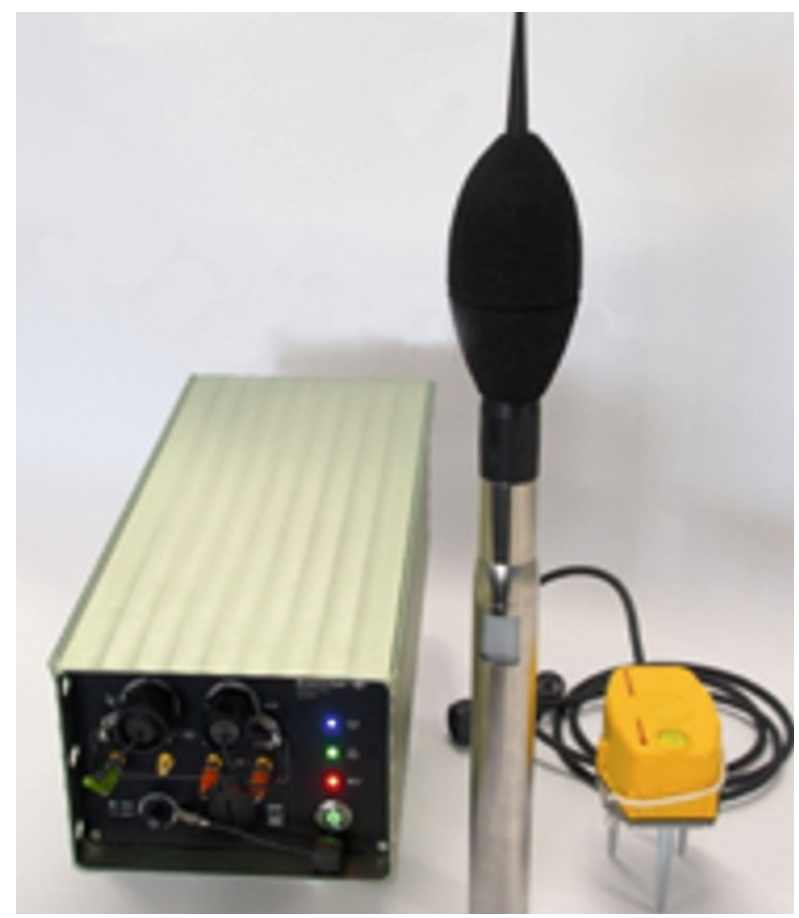

\section{BRÜEL \& KJ/ER CALIBRATION SERVICES GLOBAL EXCELLENCE, LOCAL EXPERTISE}

Thanks to factory-trained service engineers, multiple up-to-date factory calibration systems and over 40 years of experience serving Australian customers, Bruel \& Kjaer service is the partner of choice for many National and International businesses.

Bruel \& Kjaer Service provides full service, support and calibration for the complete range of Brüel \& Kjær Sound \& Vibration solutions including LDS vibration test systems.

Accredited calibration to the latest standards of:

$$
\begin{array}{ll}
\text { - Sound level meters } & \text { - Analysers (including multi-channel } \\
\text { - Calibrators } & \text { systems) } \\
\text { - Microphones } & \text { - Noise dose meters } \\
\text { - Accelerometers } & \text { - Amplifiers } \\
\text { - Vibration Meters } & \text { - Filters }
\end{array}
$$

Calibration service for non Brüel \& Kjær equipment is available, as well as rental and loan equipment on request.

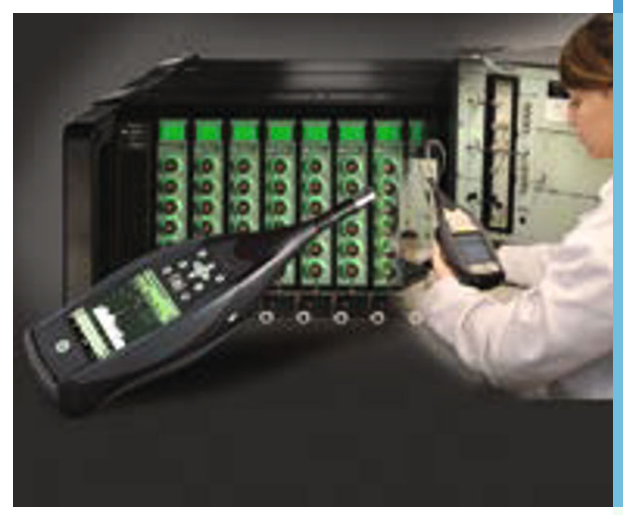

Bruel \& Kjaer Australia (HQ) Suite 2, 6-10 Talavera Road North Ryde NSW 2113

www.bksv.com auinfo@bksv.com

Tel: +61298898888

\section{Brüel \& Kjær}

BEYOND MEASURE

www.bksv.com/service 


\section{BOOK REVIEW}

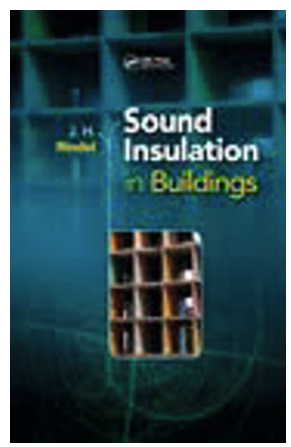

Sound Insulation in Buildings

Jens Rindel, ISBN 9781498700412 (hardback) 9781498700429 (eBook)

Published by CRC Press, 2018

Jens Rindel has an extensive background in the topic of sound in buildings, having begun to lecture in the topic in the mid1970s. He has seen the knowledge of sound insulation develop and indeed contributed much himself to the topic. Hence, he has a solid basis and deep understanding to produce a book on Sound Insulation in Buildings. Overall the book is well balanced with content to suit those newly entering the field and seeking a deeper understanding plus the detail of the theoretical analysis that a more advanced researcher or consultant may be seeking. The experience with lecturing to both undergraduate and post graduate students in reflected in the style of the book. It contains the equations but also the clear explanations of the concepts plus charts and diagrams. There is an extensive reference listing for each chapter and these include both fundamental plus more recent references.

The first chapters deal with fundamental acoustics and Chapter 5 provides the basis for the understanding of the concepts of sound insulation in buildings. The subsequent chapters then deal in more depth with topics such a radiation, statistical energy analysis plus impact and airborne sound. Chapter 13 has 30 pages dealing with measurement uncertainty; essential reading for those doing the testing and those using the data from such tests. The final chapter comprises assessment of 6 experimental buildings with high sound insulation (all northern European buildings). The discussion on each of these provides useful insights on the concepts as well as the results.

The book would be a suitable reference for courses on sound insulation in buildings plus an excellent reference book for all those working in the area from product manufacturers to acoustic consultants.

Marion Burgess is an Honorary Senior Lecturer at UNSW, Canberra. She began her career in acoustics in a testing facility for building products. She continues to be involved in a wide range of acoustics projects including teaching, research and consulting

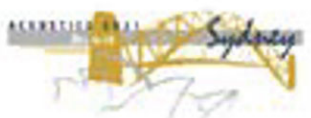

Major international conference to be held in Sydney, 6 to 10 December 2021 Register your interest now and plan for your participation

\section{Sydney2021@acoustics.asn.au}

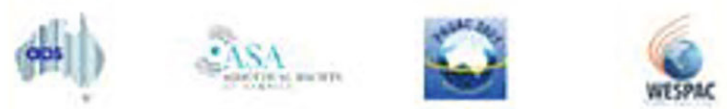

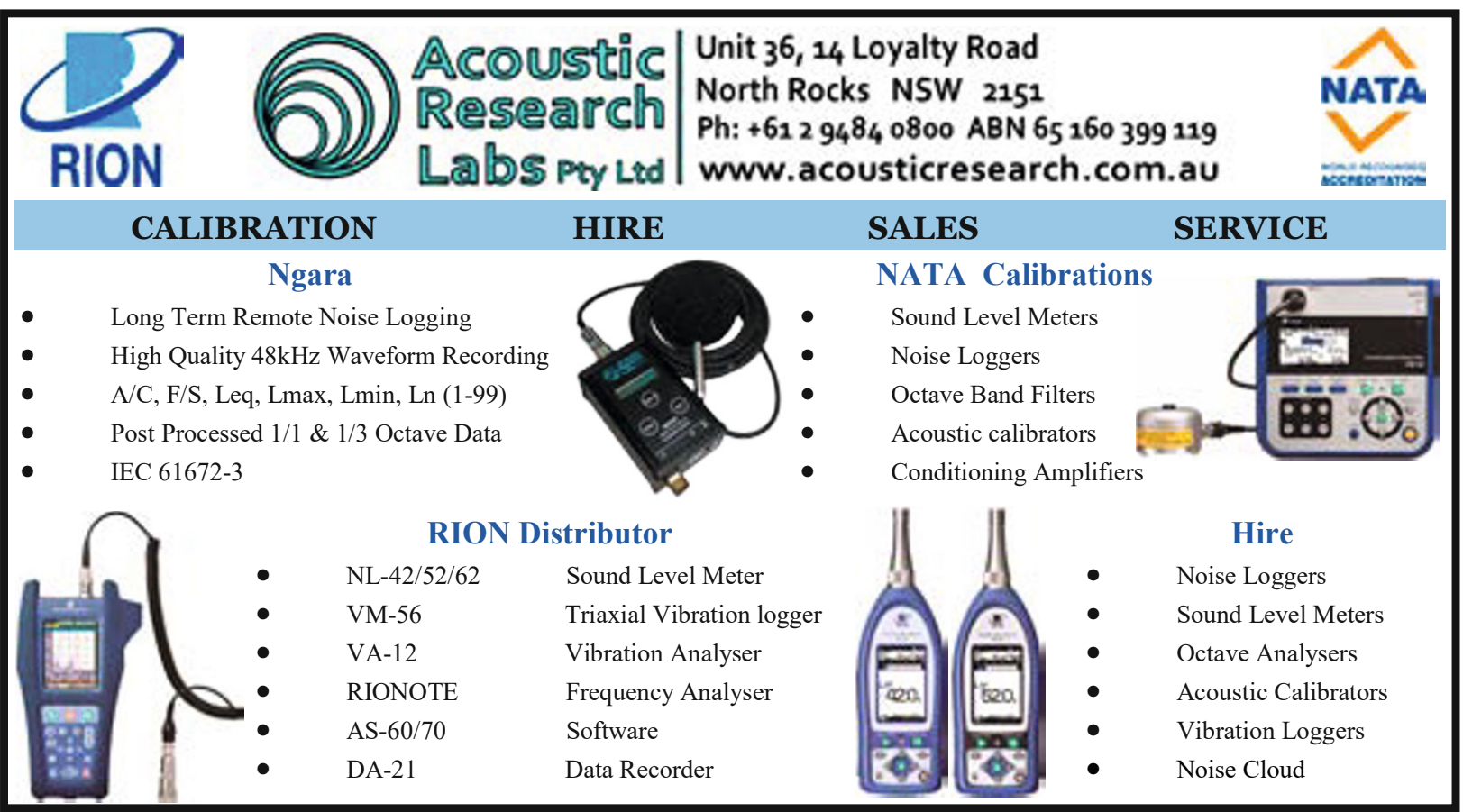




\section{NEED AN EASIER WAY TO ENSURE NOISE COMPLIANCE?}

JOB DONE.

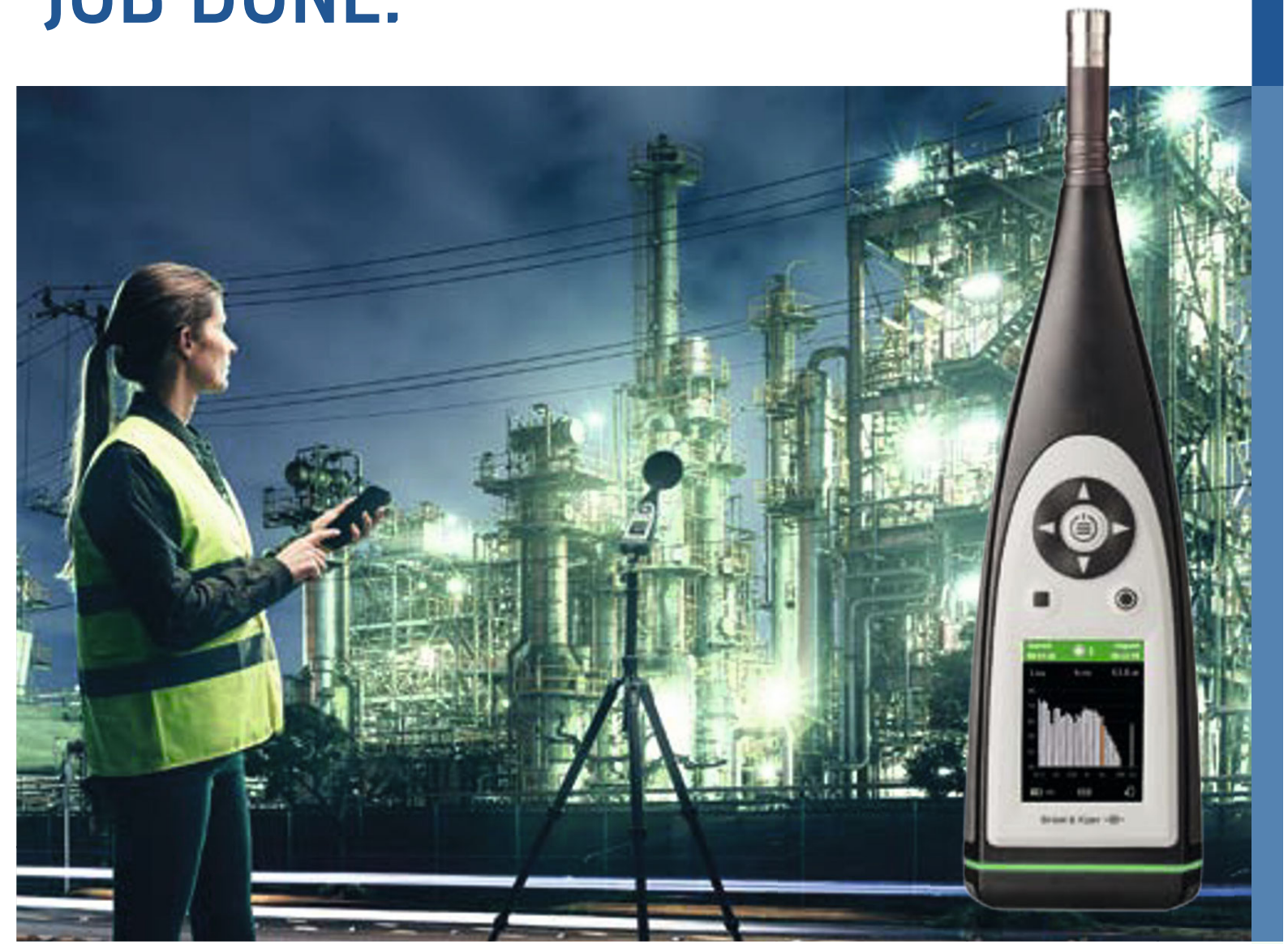

For noise measurement surveys, you need a sound level meter solution that gets your job done faster, easier and problem-free. The new B\&K 2245 gives you absolute confidence and control through user-friendly mobile apps and functionality tailored for your task, including customizable checklists, sound isolation markers, on-site analysis, photo embedding, and more.

To simplify your job-to-do, visit www.bksv.com/2245
INTRODUCING A NEW SOUND LEVEL METER DESIGNED FOR YOUR JOB.



\section{Brüel \& Kjær ${ }^{\mathrm{B}}$} BEYOND MEASURE 


\section{FUTURE CONFERENCES}

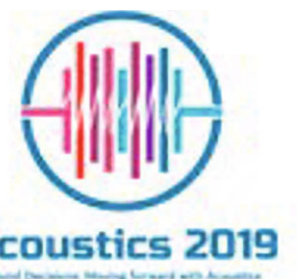

\section{Acoustics 2019, Cape Schanck}

The next Australian Acoustical Society conference: Sound Decisions: Moving forward with Acoustics will be held at the RACV Cape Schanck Resort, Mornington Peninsula, Victoria, from 10-13 November 2019.

Acoustics 2019 will host technical and plenary sessions on a range of topics, with major streams including environmental acoustics and planning, transportation noise, building acoustics and amenity. Plenary Speakers will be: Professor Irene van Kemp and Professor Jian Kang; Keynote speakers: Adjunct Professor John Davy, Dr Kym Burgmeister, Mr Mick Wimbush, Dr Stephen Moore

The conference will appeal to acoustic consultants, academics and students, legislators and authorities, and other related disciplines with an interest in acoustics such as planners, architects and environmental professionals.

Key dates:

Regular registration fees apply from 1 Aug to $10 \mathrm{Oct}$

Final paper submissions: 1 October

http://www.acoustics2019.com/

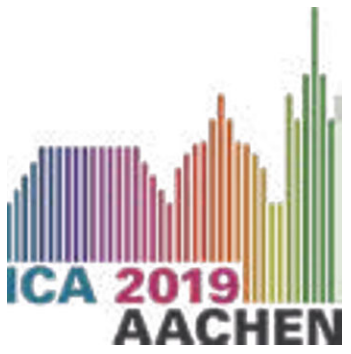

\section{ICA 2019 Aachen}

The German Acoustical Society (Deutsche Gesellschaft für Akustik, DEGA) is pleased to invite you to the 23rd International Congress on Acoustics in the beautiful and historical city of Aachen from 9 to 13 September 2019.

The technical program will include plenary, distinguished, invited, contributed, and poster papers covering all aspects of acoustics. There will be an extensive technical exposition highlighting the latest advances in acoustical products.

The congress will integrate the conference EUROREGIO of the European Acoustics Association, EAA, with invited papers focusing on European projects, educational programs, standards, and legislation.
There are also following satellite meetings:

EAA Spatial Audio Signal Processing Symposium Paris, 6-7 September, EAA Summer School Leuven, 6-8 September, International Symposium Room Acoustics, ISRA Amsterdam, 13-15 September and International Symposium Musical Acoustics, ISMA Detmold, 15-17 September.

More information: http:/www.ica2019.org/

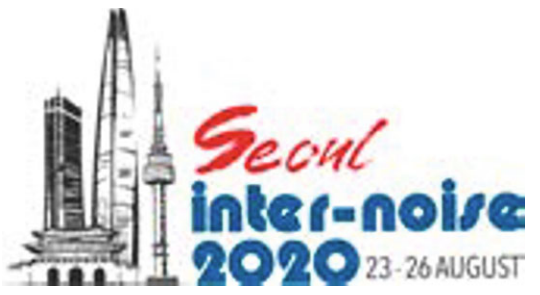

Inter-Noise 2020

The 49th International Congress and Exposition on Noise Control Engineering will be held in Seoul, Korea, 23-26 August 2020. The Congress is hosted by the Korean Society for Noise and Vibration Engineering (KSNVE) on behalf of the International Institute of Noise Control Engineering (I-INCE). The theme of the Congress is 'Advances in Noise and Vibration Control Technology', and it will be held in COEX Convention Center, Seoul, Korea.

INTER-NOISE 2020 will provide the best opportunity for engineers and scientists in all fields of acoustics to learn about and share their work with colleagues from around the world. Two plenary lectures, three keynote lectures and more than a hundred technical sessions will be organized for the exchanging of views and sharing of experiences. We believe that this congress will be an invaluable experience for all participants and a great opportunity to create new memories with the Inter-Noise family in the beautiful city of Seoul.

http://internoise2020.org

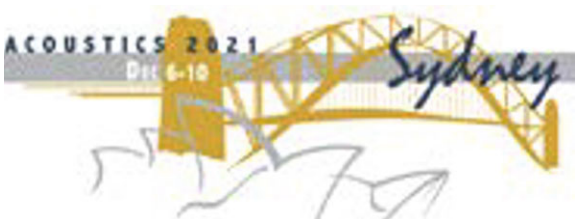

Acoustics 2021, Sydney

The Acoustical Society of America (ASA) and the Australian Acoustical Society (AAS) are joining together to co-host Acoustics 2021, Sydney, which will also incorporate the Western Pacific Acoustics Conference (WESPAC) and the Pacific Rim Underwater Acoustics Conference (PRUAC).

The conference will be held at the International Convention Centre, Darling Harbour, Sydney. This Convention Centre has been completely rebuilt and opened in late 2017, so it features state of the art facilities along with the magnificent views of Sydney. Register your interest now and plan for your participation.

Sydney2021@acoustics.asn.au 


\section{Sustaining Members}

The following are Sustaining Members of the Australian Acoustical Society. Full contact details are available from http://www.acoustics.asn.au/sql/sustaining.php

3M AUSTRALIA

www.3m.com

ACOUSTIC RESEARCH LABS

www.acousticresearch.com.au

ACOUSTICA

www.acoustica.com.au

ACRAN

www.acran.com.au

ACU-VIB ELECTRONICS

www.acu-vib.com.au

ADAMSSON ENGINEERING

www.adamsson.com.au

AERISON PTY LTD

www.aerison.com

ARMSTRONG WORLD INDUSTRIES www.armstrongceilings.com.au

ASSOCIATION OF AUSTRALIAN ACOUSTICAL CONSULTANTS

www.aaac.org.au

BORAL PLASTERBOARD

www.boral.com.au/plasterboard

BRUEL \& KJAER AUSTRALIA

www.bksv.com.au

C-MAC INDUSTRIES

www.cmac.com.au

CSR BRADFORD INSULATION

www.bradfordinsulation.com.au
DYNAMIC COMPOSITE

TECHNOLOGIES

www.dctech.com.au

EMBELTON

www.vibrationisolation.com.au

EMS BRUEL \& KJAER

www.emsbk.com

FLETCHER INSULATION PTY LTD

www.insulation.com.au

KNAUF AMF AUSTRALIA PTY. LTD.

www.knaufamf.com.au

MASON MERCER AUSTRALIA

www.masonmercer.com.au

NSW ENVIRONMENT PROTECTION

AUTHORITY

www.epa.nsw.gov.au

PYROTEK NOISE CONTROL www.pyroteknc.com

REGUPOL (AUSTRALIA) PTY LTD

www.regupol-vibration-technology.com.au

SOUNDBLOCK ${ }^{\circledR}$ SOLUTIONS

www.soundblock.com.au

THE P.A. PEOPLE PTY LTD

www.papeople.com.au

VIBRATION SOLUTIONS

https://vibrationsolutions.com.au/

VIPAC ENGINEERS AND SCIENTISTS www.vipac.com.au 


\section{DIARY}

\section{9}

3 - 6 September, Bruges, Belgium International Congress on Ultrasonics (2019 ICU Bruges)

kuleuvencongres.be/2019icu/home

6 - 7 September, Paris, France

EAA Spatial Audio Signal Processing

Symposium (SASP)

https://sasp2019.ircam.fr

8 - 13 September, Aachen, Germany 23rd International Congress on Acoustics (ICA 2019)

www.ica2019.org

13 - 17 September, Detmold, Germany International Symposium on Musical Acoustics (ISMA 2019)

www.isma2019.de

15 - 17 September, Amsterdam, Netherlands

International Symposium on Room Acoustics (ISRA 2019)

www.isra2019.eu
10 - 13 November, Mornington

Peninsula, Victoria, Australia

Acoustics 2019

Annual Conference of Australian

Acoustical Society

www.acoustics2019.com

\section{0}

20 - 24 April, Lyon, France

Forum Acusticum 2020

fa2020.universite-lyon.fr

11 - 15 May, Chicago, Illinois

179th Meeting of the Acoustical Society of America

www.acousticalsociety.org

15-18 June, Stockholm, Sweden

13th ICBEN Congress on Noise as a

Public Health Problem

icben2020@akademikonferens.se

12 - 16 July, Prague, Czech Republic 27th International Congress on Sound and Vibration (ICSV27)

iiav.org

23 - 26 August, Seoul, Korea

INTER-NOISE 2020

internoise2020.org/

9 - 13 November, Cancun, Mexico 180th Meeting of the Acoustical Society of America

www.acousticalsociety.org

\section{1}

26 - 28 January, Auckland, New

Zealand

Noise and Vibration Emerging Methods (NOVEM 2021)www.novem2021.ac.nz

\section{5 - 29 July, Singapore}

28th International Congress on Sound and Vibration (ICSV28)

iiav.org

1 - 4 August, Washington, USA

INTER-NOISE 2021

Www.i-ince.org/

6-10 December, Sydney, Australia Acoustics 2021, Sydney

Joint meeting AAS, ASA, Wespac and PRUAC Sydney2021@acoustics.asn.au

\section{2}

24 - 28 October, Gyeongju, Korea 24th International Congress on Acoustics (ICA 2022)

http://www.icacommission.org/calendar. html

Meeting dates can change so please ensure you check the conference website: http://www.icacommission. org/calendar.html

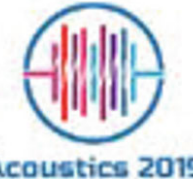

\section{Acoustics 2019, Cape Schanck, Vic 10-13 November 2019}

\section{Sound Decisions: Moving forward with Acoustics}

Australian Acoustical Society Annual Conference

Plenaries, Keynotes, Technical Sessions, Exhibition, Social events

Regular registration fees 1 August to 10 October, wWw.acoustics2019.com 